\section{Pengembangan Sistem Perekaman dan Manajemen Data Survei Inventarisasi Sumberdaya Mineral MODA- AWA Versi 3.0}

\author{
Nurhakim ${ }^{1}$ \\ 1 Program Studi Teknik Pertambangan, Fakultas Teknik, \\ Universitas Lambung Mangkurat
}

nurhakim@ulm.ac.id

\section{Pendahuluan}

Inventarisasi sumberdaya mineral adalah kegiatan pencatatan, penggambaran, perekaman, pengambilan dan manajemen data serta informasi sumberdaya mineral, baik yang bersifat data primer maupun sekunder yang diperoleh dari hasil kegiatan eksplorasi. Hasil dari inventarisasi ini dapat berupa pembuatan neraca sumberdaya suatu daerah, penambahan data untuk membuat rencana eksplorasi suatu daerah, maupun dalam penentuan suatu daerah prospek (Pusat Sumberdaya Geologi, 2014). Untuk memenuhi keperluan ini, selama beberapa dekade terakhir, industri pertambangan telah memanfaatkan teknologi informasi dan komunikasi. Bahkan, teknologi informasi dan komunikasi dimanfaatkan secara masif pada setiap tahapan pertambangan; sejak tahap prospeksi, eksplorasi, eksploitasi, ekstraksi metalurgi dan refineri, sampai dengan pengangkutan dan pemasaran (Nurhakim, 2002). Inventarisasi Sumber Daya Mineral merupakan awal dari terciptanya Sistem informasi
Inventarisasi sumberdaya mineral adalah kegiatan pencatatan, penggambaran, perekaman, pengambilan dan manajemen data serta informasi sumberdaya mineral, baik data primer maupun sekunder, yang diperoleh dari hasil kegiatan eksplorasi. Data dan informasi yang dikelola dalam kegiatan inventarisasi didapatkan dari proses bisnis Sistem Informasi Eksplorasi (Exploration Information System - EIS), yang terdiri dari tiga tahapan, yaitu input, pengelolaan, dan pemutakhiran data. Penulis telah mengembangkan dua versi sistem perekaman data EIS, yaitu MODA-AWA Versi 1.o (berbasis dBase) dan Versi 2.o (berbasis MS-Access). Kedua versi ini dijalankan single-user secara offline di komputer stand-alone. Sejalan dengan perkembangan teknologi dan kebutuhan praktis di lapangan, Penulis mengembangkan Versi 3.o. Versi ini dikembangkan dengan mengoptimalkan fitur yang dimiliki Form online dan diintegrasikan dengan Aplikasi Sistem Informasi Geografis, dengan mempertimbangkan standar yang diatur dalam regulasi dan pedoman yang berlaku di Indonesia. Pada saat awal pengembangan MODA-AWA Versi 3.0 ini, data lokasi didapatkan berdasarkan koordinat yang terdapat pada gadget. Namun dari beberapa kegiatan percobaan di lapangan, koordinat yang terbaca pada gadget kurang akurat dan presisi bila dibandingkan dengan koordinat yang didapatkan dari GPS. Untuk mengantisipasi hal ini, dilakukan modifikasi terhadap formulir survei, dimana data koordinat diinput secara manual dengan data yang didapatkan dari GPS dan menambahkan sesi kontrol.

Kata kunci: Survei Lapangan, Inventarisasi, Sumberdaya Mineral, Exploration Information System (EIS)

Diajukan: 1 Juni 2020

Direvisi: 16 Juni 2020

Diterima:17 Juni 2020

Dipublikasikan online17 Juni 2020:

Sumber Daya Mineral, yang merupakan sumber informasi bagi pembuatan kebijakan dalam pengelolaan sumber daya alam (Charoenbunwanon, et al., 2016).

Penulis telah mengembangkan dua versi sistem manajemen data survei lapangan yang diberi nama MODA-AWA. Sistem perekaman data ini dikembangkan menggunakan aplikasi dBase (Versi 1.0) dan Microsoft Access (Versi 2.0). Pada kedua versi ini, data survei / eksplorasi dicatat pada Form Rekaman Data Lapangan secara manual, selanjutnya dikumpulkan dan didijitasi setelah survei selesai, dan selanjutnya dilakukan analisis secara digital (Nurhakim, 2000). Data lapangan yang direkam dengan kedua versi ini berjalan secara kompatibel dengan aplikasi Sistem Informasi Geografis (Nurhakim, 2006). Namun kedua versi ini memiliki kelemahan, yaitu hanya dapat dijalankan 1 orang pengguna (single-user) secara offline di komputer stand-alone.

Dengan berkembangnya teknologi sistem informasi dan komunikasi, saat ini telah banyak aplikasi database online yang terintegrasi dengan aplikasi SIG (Web-GIS /

Cara mensitasi artikel ini:

Nurhakim (2020) Pengembangan Sistem Perekaman dan Manajemen Data Survei Inventarisasi Sumberdaya Mineral MODA-AWA Versi 3.0. Buletin Profesi Insinyur 3(1) 051-056 
Mobile-GIS), yang didefinisikan sebagai suatu sistem informasi yang mengijinkan penggunanya untuk melihat, mengedit dan memanipulasi data spasial melalui web (de Smith et al., 2018).

Keberadaan WebGIS sangat membantu kegiatan eksplorasi mineral, terutama dalam pengumpulan, penanganan dan penyimpanan data dalam jumlah yang sangat besar (big data). WebGIS telah menunjukkan peranannya dalam proses pengambilan keputusan berbasis data yang sangat kompleks secara komprehensif (Yousefi, et at., 2019). Flow diagram dari pemanfaatan sistem GIS dalam eksplorasi mineral ditampilkan pada Gambar 1 (Haldar, 2018).

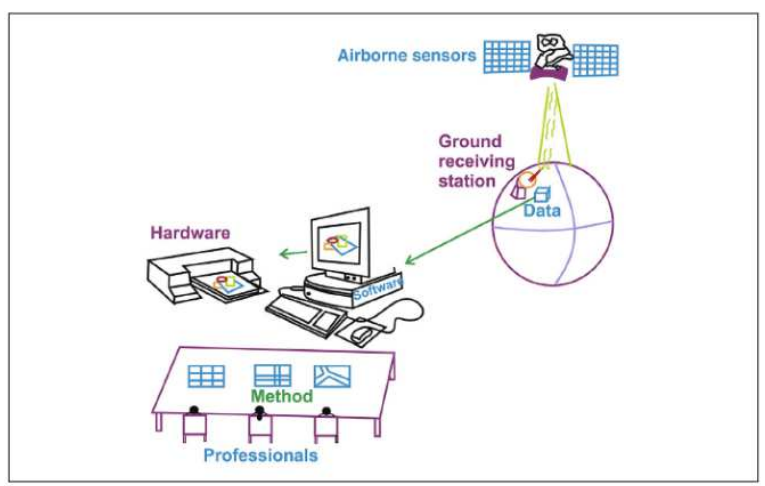

Gambar 1 Flow Diagram GIS (Haldar, 2018)

Demikian besar peluang pemanfaatan WebGIS dalam eksplorasi, namun dalam praktik di lapangan, berbagai kemudahan yang dimiliki oleh Sistem Informasi Eksplorasi (EIS) berbasis WebGIS seringkali tidak dapat berjalan secara optimal disebabkan adanya beberapa kendala. Harga aplikasi WebGIS komersil yang relatif mahal, kebutuhan perangkat komputer dengan spesifikasi khusus, dan biaya hosting serta keterbatasan akses internet adalah beberapa kendala dalam penerapan teknologi ini (Prahasta, 2006).

Menurut Speedtest Global Index, koneksi internet di Indonesia pada bulan Mei 2019 berada di posisi ke112 dunia, dengan rata-rata kecepatan mengunduh (download) file sebesar 17,02 Mbps. Untuk rata-rata kecepatan mengunggah (upload) file sebesar 10,44 Mbps, Indonesia berada di peringkat ke-123 dunia (Speedtest.net, 2019). Konektivitas internet ini akan lebih buruk kondisinya pada daerah target eskplorasi, yang biasanya berada di daerah terpencil (remote area). Hal ini menjadi faktor penyebab utama sulitnya memanfaatkan WebGIS sebagai tool dalam sistem informasi eksplorasi. Hal ini pula yang menjadi latar belakang keinginan penulis mengembangkan MODAAWA versi 3.0 yang dapat diinput secara online, mengakomodir multi-user, tetapi tidak memerlukan hosting / server dan komputer berspesifikasi khusus, serta dapat dioperasikan dengan mudah oleh teknisi / tenaga survei di lapangan.

\section{Metode}

Dalam survei konvensional, data yang diperoleh di lapangan harus ditulis di buku catatan lapangan. Setelah survei selesai, seluruh anggota tim berkumpul untuk mengkompilasi dan mendijitalkan data tersebut. Setelah itu dilakukan analisis terhadap data dijital yang dihasilkan. Pengembangan WebGIS atau MobileGIS menyederhanakan proses ini dan memerlukan waktu yang lebih sedikit untuk proses digitalisasi dan analisis. Pekerja lapangan dapat merekam data digital dengan sistem ini di lapangan dengan gadget mereka. Namun, penggunaan Mobile GIS memerlukan dana yang besar karena mereka terutama menggunakan aplikasi GIS komersial (Nakayama and Suguru, 2012).

Brovelli, et al., (2017) mengemukakakan bahwa sebenarnya perangkat lunak open-source untuk aplikasi geospasial (FOSS4G) telah tersedia dan mulai digunakan. Perangkat lunak ini telah cukup matang, memiliki kapabilitas dan andal. Untuk itu, dalam pelaksanaan survei dan pengembangan Sistem Informasi Eksplorasi, yang lebih diperlukan adalah pemenuhan kebutuhan untuk dapat melakukan perekaman data lapangan secara multi-user dan dapat berjalan baik pada bandwith internet yang minim. Hal ini dapat dipenuhi oleh formulir online berbasis web.

Farmer et.al. (2016) telah melakukan review terhadap 10 free online Survey Tools. Sebagai konklusi, Farmer merekomendasikan eSurv (http://esurv.org) dan Qualtrics (https://www.qualtrics.com). Di samping itu, Google forms (https://www.google.com/forms) dan KwikSurvey (https://kwiksurveys.com) dinyatakan juga memenuhi seluruh syarat.

Berdasarkan uraian yang telah disampaikan, maka tujuan dari penulisan artikel ini adalah untuk merancang dan mengembangkan sistem perekaman data secara online, mengakomodir multi-user, tetapi tidak memerlukan hosting / server dan komputer berspesifikasi khusus, serta dapat dioperasikan dengan mudah oleh teknisi / tenaga survei di lapangan menggunakan gadget, tanpa harus terus menerus terkoneksi dengan jaringan internet.

\section{Hasil Kerja}

\section{Struktur Data}

Pada dasarnya, struktur data yang ada pada Sistem Inventarisasi Sumber Daya Mineral dirancang untuk dapat mengakomodir delapan layer peta dasar dalam "The National Map" (Gambar 2) yang dikembangkan oleh USGS bersama beberapa biro dan departemen di Amerika Serikat (Sugarbaker and Carswell, 2011).

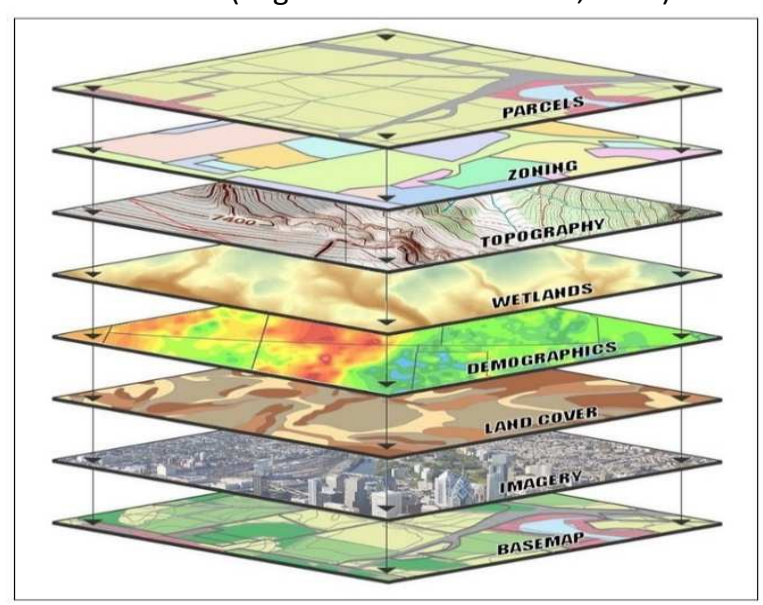

Gambar 2 Delapan layer peta dasar The National Map 
Adapun Struktur data survei lapangan yang direkam dalam Sistem Informasi Eksplorasi MODA-AWA Versi 3.0 mengacu kepada SNI 4726 : 2019 tentang Pedoman Pelaporan, Sumberdaya, dan Cadangan Mineral, dan SNI 5015 : 2019 tentang Pedoman Penyusunan Sumber Daya dan Cadangan Batubara, sehingga dapat memenuhi kriteria yang dipersyaratkan pada poin 8.1.1. SNI 6728 : 42015 Tentang Penyusunan Neraca Spasial Sumber Daya Alam Bagian 4: Sumber Daya dan Cadangan Mineral dan Batubara. Secara garis besar struktur data ini dapat dilihat pada Gambar 3.

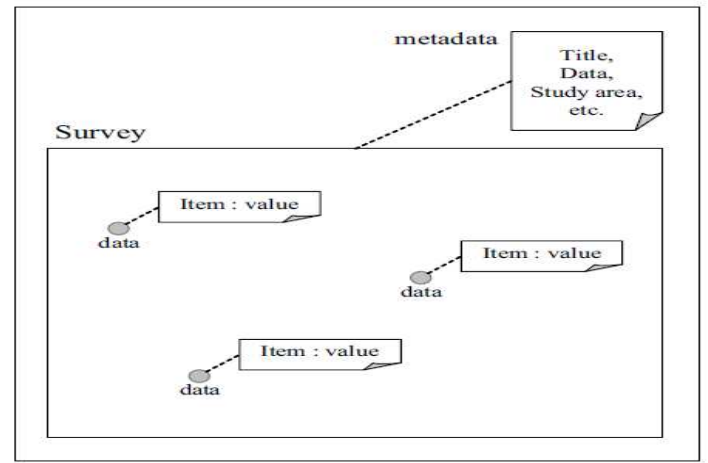

Gambar 3 Simplifikasi Struktur data MODA-AWA

\section{Diagram Alir / Proses Bisnis}

Diagram alir pengembangan Sistem Perekaman dan Manajemen Data Survei Inventarisasi Sumberdaya Mineral MODA-AWA dapat dilihat pada Gambar 4.

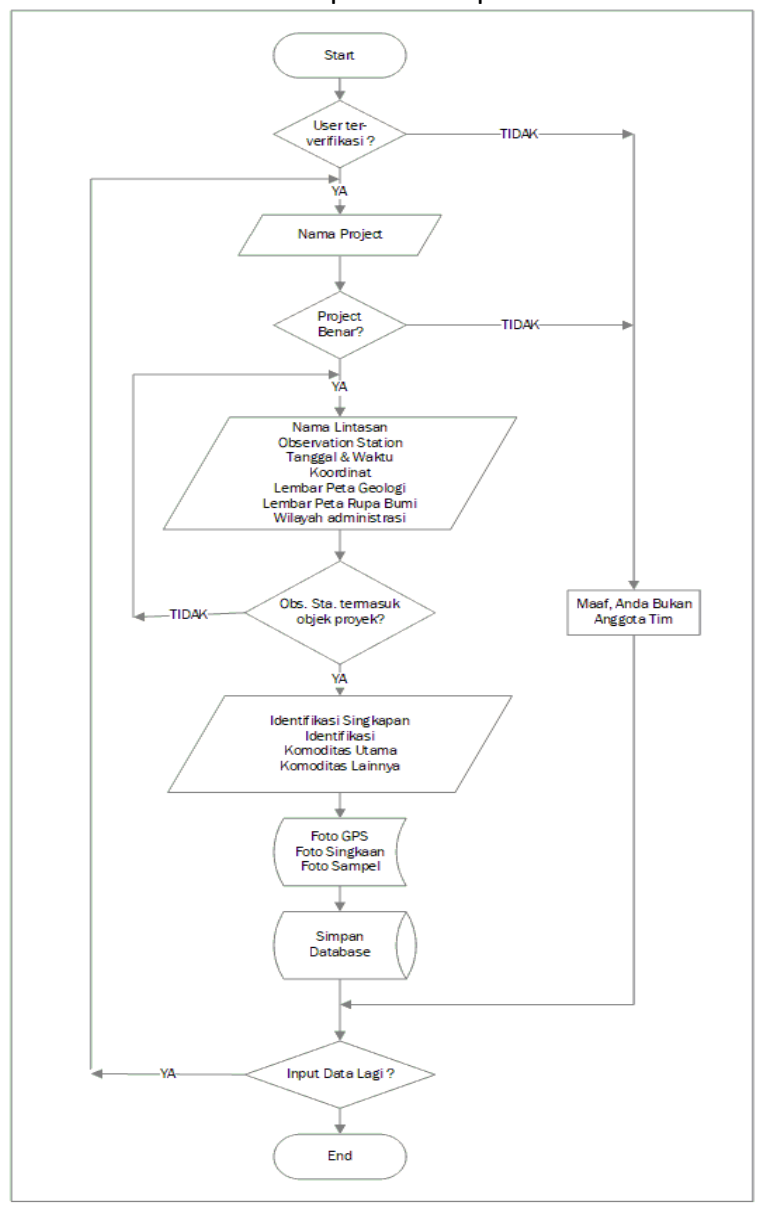

Gambar 4 Diagram Alir pengembangan MODA-AWA

\section{Pengembangan Sistem}

Sistem perekaman dan manajemen data ekplorasi MODA-AWA dikembangkan sesuai proses bisnis yang telah disusun sebelumnya. Proses ini secara garis besar terdiri dari tiga tahapan, yaitu input data, pengelolaan data dan pemutakhiran data. Mengacu pada Gambar 4, field yang terdapat dalam MODA-AWA Versi 3.0 disusun sebagaimana ditampilkan pada Gambar 5.

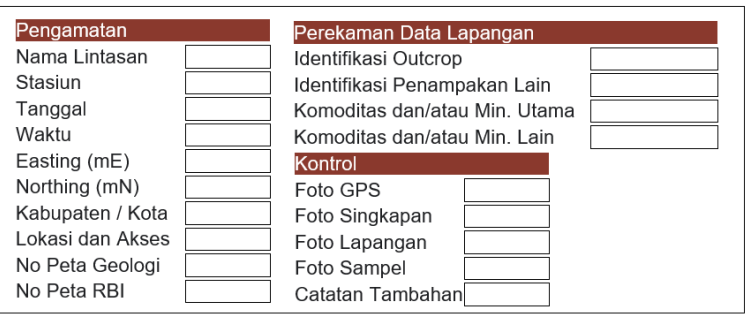

Gambar 5 Field pada MODA-AWA Versi 3.0

Sebagaimana umumnya konfigurasi sistem dengan model client-server, para surveyor / fieldworker yang melakukan survei di beberapa lokasi secara simultan, juga dapat menginput data di saat yang bersamaan (Gambar 6), dimana terminal klien digambarkan sebagai laptop, PDA, atau Smartphone. Dalam sistem yang dikembangkan, data koordinat lokasi survei tetap diwajibkan menggunakan perangkat GPS karena koordinat yang didapatkan lebih akurat.

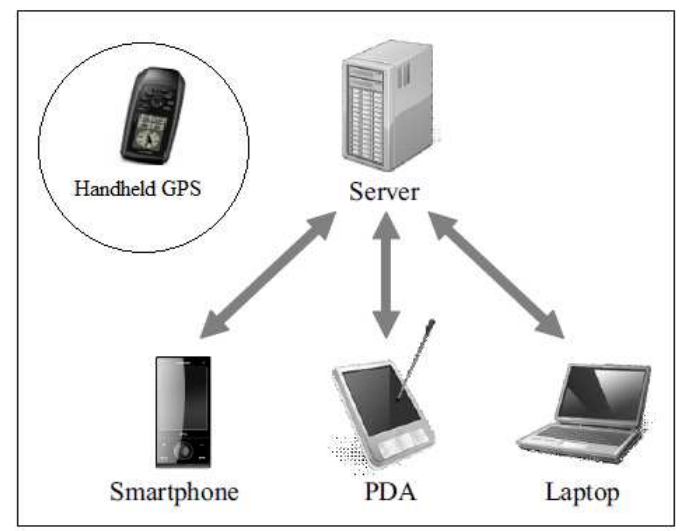

Gambar 6 Client Terminals

Untuk memulai MODA-AWA Versi 3.0, pengguna cukup melakukan scanning QD-Code yang telah disiapkan (Gambar 7).

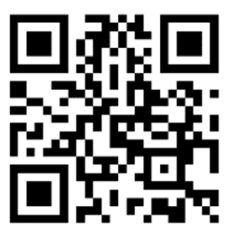

Gambar 7 QR-CodeMODA-AWA Versi 3.0

\section{Implementasi Sistem}

Tampilan awal dari Sistem Perekaman dan Manajemen Data Survei Inventarisasi Sumberdaya Mineral - Sistem Informasi Eksplorasi MODA-AWA dapat dilihat pada Gambar 8. 


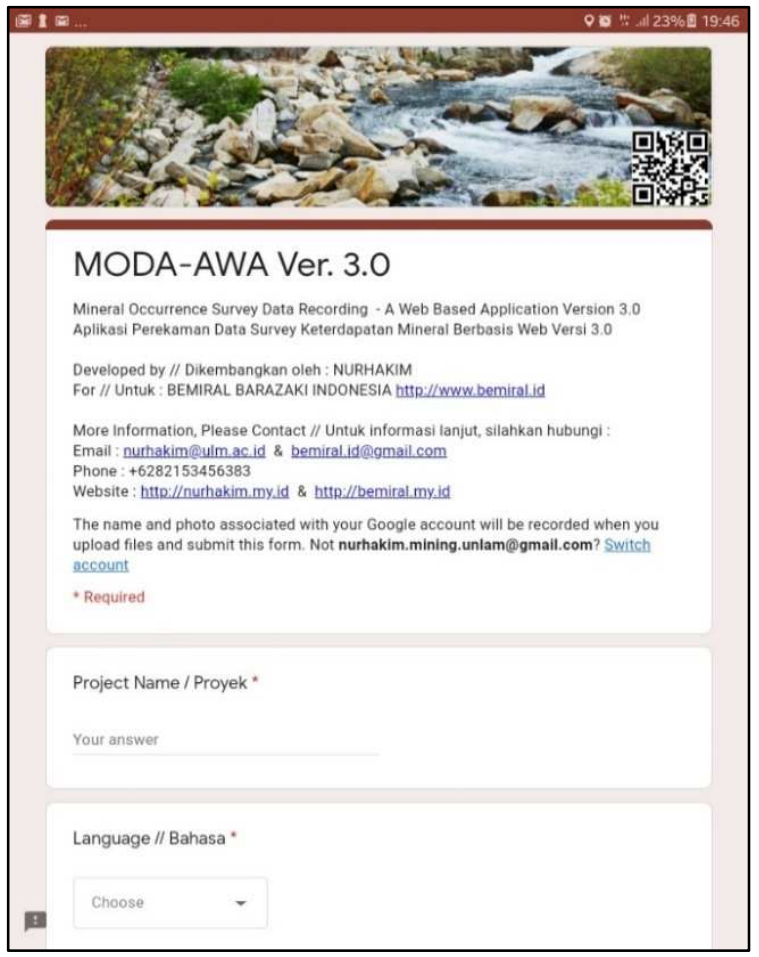

Gambar 8 Tampilan Awal MODA-AWA Ver. 3.0

Sistem ini telah diimplementasikan oleh penulis dan tim survei beberapa kegiatan inventarisasi sumberdaya mineral dan batubara di beberapa provinsi dan kabupaten/kota yang ada di Indonesia, antara lain kegiatan Pemetaan potensi sebaran aquifer Kabupaten Kotabaru, Survei hidrologi Kawasan Sebelimbingan Kabupaten Kotabaru, Inventarisasi rencana wilayah pertambangan rakyat Kabupaten Tapin, Pemetaan wilayah dan potensi sumber daya alam Kabupaten Balangan, Penyusunan profil daerah rawan bencana Kabupaten Tapin, Inventarisasi sebaran dan kualitas bahan galian konstruksi jalan dan jembatan Propinsi Kalimantan Selatan, dana beberapa kegiatan lainnya. Di samping itu, MODA-AWA juga telah dimanfaatkan untuk merekam data eksplorasi di industri pertambangan, antara lain keberadaan mineral logam di Pulau Sebuku Kabupaten Kotabaru, Kabupaten Banjar, Kabupaten Tanah Laut (Propinsi Kalimantan Selatan) dan Kabupaten Katingan, Kabupaten Lamandau, Kabupaten Sukamara (Propinsi Kalimantan Tengah), serta beberapa tambang batubara.

Selain kegiatan-kegiatan di atas, sistem ini juga diaplikasikan dalam kegiatan Penelitian dan Pengabdian Kepada Masyarakat yang dilakukan oleh penulis dan rekan-rekan. Beberapa publikasi dari kegiatan tersebut antara lain : Identifikasi potensi endapan bijih besi laterit di bagian tengah Pulau Sebuku (Nurhakim, dkk, 2016), Inventarisasi keterdapatan mineral dan batuan untuk bahan baku batu permata (Akkas, A.M., dkk, 2017), Permodelan endapan laterit di Desa Kiram, Karang Intan, Kabupaten Banjar, Kalimantan Selatan (Fuady, M., dkk, 2018), Inventarisasi keterdapatan batuan untuk material konstruksi jalan di Kecamatan Bati-Bati dan sekitarnya (Saputra, J.E., dkk, 2019), Perancangan Sistem Informasi Cadangan Batugamping berbasis web pada PT Pama Indo (Syahid, A., dkk, 2017), dan Studi rencana wilayah pertambangan rakyat Menggunakan Sistem Informasi Geografis di wilayah Kecamatan Kahayan Tengah (Tryono, A., dkk, 2017).

Data-data yang direkam MODA-AWA selanjutnya diintegrasikan dengan aplikasi Sistem Informasi Geografis serta penyusunan laporan kegiatan. Tampilan dari rekaman data dalam bentuk tabulasi dapat dilihat pada Gambar 9. Adapun integrasi MODA-AWA dengan Aplikasi Sistem Informasi Geografis dalam format peta dapat dilihat pada Gambar 10 dan Gambar 11.

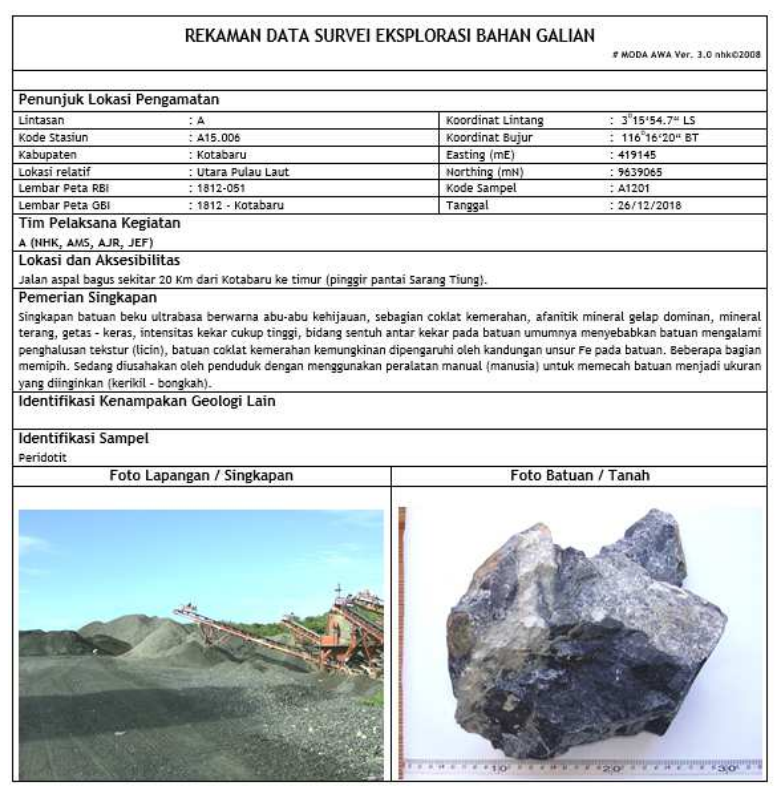

Gambar 9 Tabulasi output MODA-AWA Ver. 3.0

\section{Evaluasi}

Pada saat awal pengembangan sistem, data lokasi akan terinput secara otomatis menggunakan koordinat yang terdapat gadget/smartphone. Namun dari beberapa kegiatan survei di lapangan, koordinat yang terbaca pada gadget kurang akurat dan tidak presisi bila dibandingkan dengan koordinat yang didapatkan di GPS. Untuk mengantisipasi kendala ini, dilakukan modifikasi terhadap formulir survei, dimana data lokasi diinput secara manual menggunakan koordinat yang ditampilkan GPS, dan untuk meminimalisir kesalahan input data koordinat serta menjalankan fungsi kontrol, sistem mewajibkan pengguna sistem mengunggah foto layar GPS untuk melengkapi foto singkapan, foto sampel dan foto lapangan (Gambar 12).

Di samping modifikasi yang dilakukan di atas, terdapat beberapa hal penting yang diperoleh setelah melalukan evaluasi terhadap pengembangan dan implementasi MODA-AWA Versi 3.0 ini, antara lain : pengguna lebih mudah untuk melakukan ekspor dan impor rekaman data dalam format CSV; dengan mengaktifkan fitur notifikasi setiap kali surveyor di lapangan selesai menginput data dapat diketahui oleh anggota tim lain; integrasi dengan aplikas Sistem Informasi Geografis dapat dilakukan dengan mudah, demikian pula dengan integrasi dengan sistem pelaporan kegiatan inventarisasi sumberya mineral. 


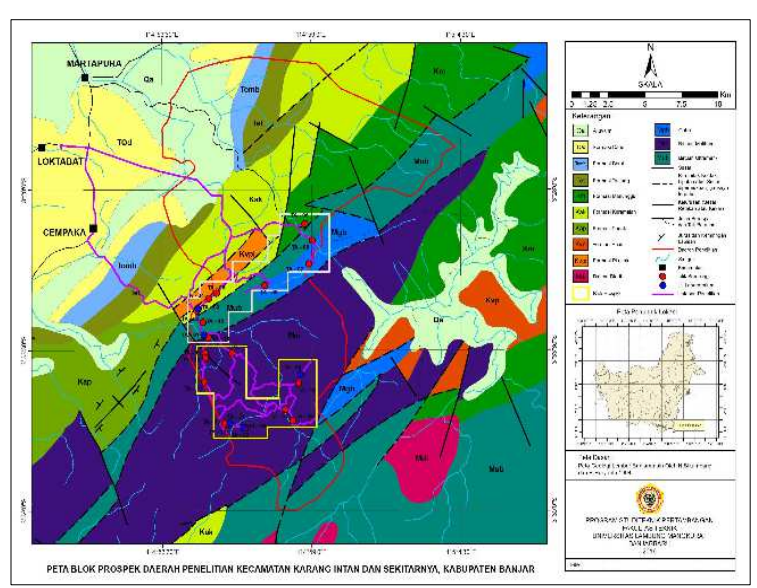

Gambar 10 Peta hasil integrasi MODA-AWA Ver. 3.0 dengan SIG untuk Inventarisasi Bahan Galian Logam

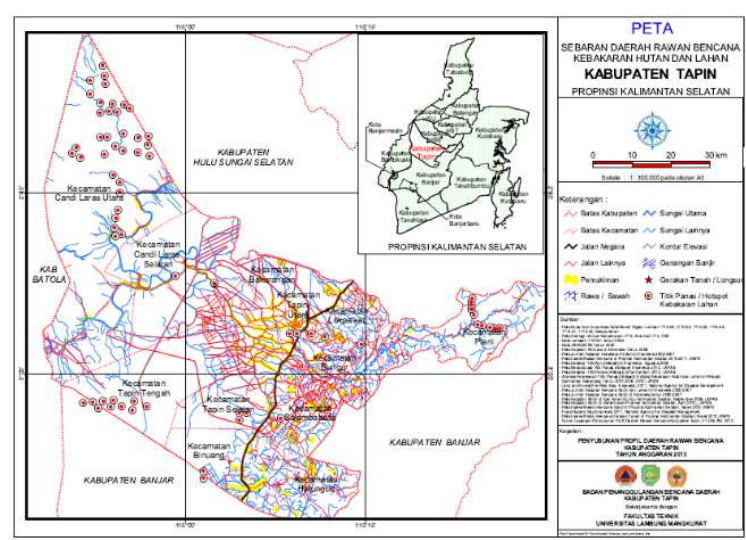

Gambar 11 Peta hasil integrasi MODA-AWA Ver. 3.0 dengan SIG untuk sebaran Daerah Rawan Bencana

\section{Control // Kontrol}

\section{Image of GPS // Foto GPS}

Upload foto GPS yang menampilkan Kode Waypoint dan Koordinat GPS Stasiun Pengamatan

¿ Add File

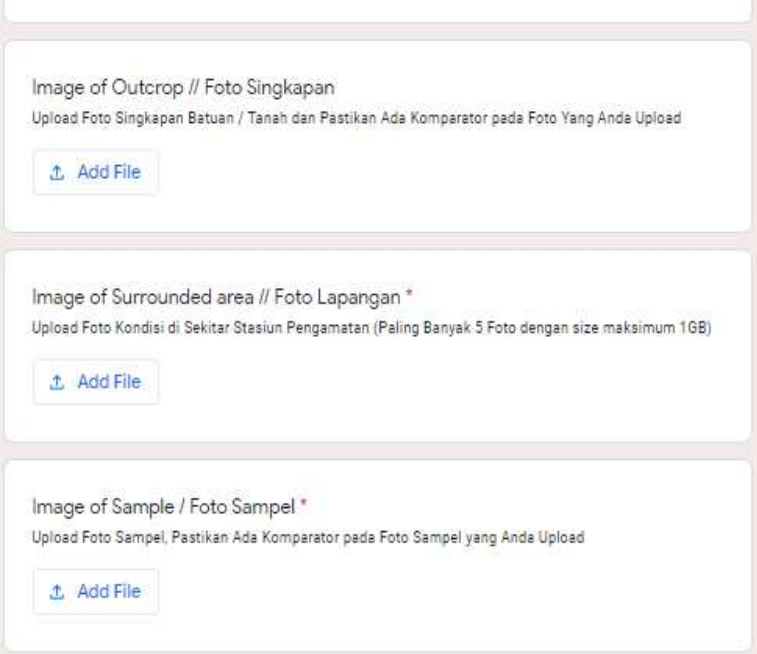

Gambar 12 Tampilan Sesi Kontrol pada MODA-AWA Ver. 3.0

\section{Kesimpulan}

1. MODA-AWA Versi 3.0 dapat menjalankan peran sebagai sistem perekaman data yang dapat diinput secara online, mengakomodir multi-user, tetapi tidak memerlukan hosting / server dan komputer berspesifikasi khusus, serta dapat dioperasikan dengan mudah oleh teknisi / tenaga survei di lapangan menggunakan gadget.

2. Berdasarkan evaluasi terhadap implementasi MODA-AWA Versi 3.0 di lapangan, telah dilakukan modifikasi terhadap formulir survei untuk mendapatkan koordinat yang lebih presisi dan akurat, dan dilengkapi sesi kontrol.

3. Implementasi Sistem Informasi MODA-AWA Versi 3.0 (dan sejenisnya) sangat diperlukan mengingat besar dan beragamnya potensi sebaran bahan galian di Indonesia, khususnya Pulau Kalimantan.

4. Bahan galian adalah sumberdaya alam yang tak terbarukan, sehingga memerlukan kebijaksanaan dalam pengelolaan dan pemanfaatannya. Keberadaan Sistem Informasi Eksplorasi yang baik akan dapat mendukung basis data inventarisasi sumberdaya mineral. Dengan demikian konservasi akan dapat berlangsung dengan baik dan degradasi lingkungan dapat dikurangi.

5. Pengembangan dan implementasi Sistem Informasi Eksplorasi (EIS) MODA-AWA Versi 3.0 sangat membantu tim surveyor / teknisi lapangan dalam pelaksanaan berbagai kegiatan di bidang Rekayasa Pertambangan, khususnya Eksplorasi Sumber Daya Bumi dan Inventarisasi Sumber Daya Mineral dan Batubara.

\section{Ucapan Terimakasih}

Terimakasih kepada Manajemen PT Adiya Widyajasa dan Bemiral Barazaki Indonesia(d/h Ylmira), serta institusi pemerintahan (Kementerian, Badan dan Dinas terkait), pemegang IUP, dan seluruh rekanan yang telah dan akan mempercayakan pelaksanaan kegiatan survei, eksplorasi dan inventarisasi sumber daya mineral dan batubara kepada penulis dan tim. Ucapan terimakasih juga disampaikan kepada Rektor Universitas Lambung Mangkurat, Dekan FT-ULM, Pengelola PS-PPI, Sejawat di PS Teknik Pertambangan dan ranger SSK Studio Permodelan dan Perencanaan Tambang FT-ULM.

\section{Referensi}

Akkas, A. M., Nurhakim, N., Riswan, R., \& Kurniawan, H. B. (2017). Inventarisasi Keterdapatan Mineral Dan Batuan Untuk Bahan Baku Batu Permata. Jurnal Geosapta, 2(2). 2. 10.20527/jg.v2i2.4214.

Brovelli, M.A., Minghini, M., Moreno-Sanchez, R., \& Oliveira, R. (2017) Free and open source software for geospatial applications (FOSS4G) to support Future Earth, International Journal of Digital Earth, 10:4, 386404, DOI: 10.1080/17538947.2016.1196505

Charoenbunwanon, N., Wakita, K., \& Bandibas, J. (2016). Web-based Mineral Information System of Thailand Using Free and Open Source Software and Open Geospatial Consortium: Standards: A Case Study of 
ASEAN Region. Geoinformatics. 27. 31-39. 10.6010/geoinformatics.27.2_31.

de Smith M. J., Goodchild, M. F., and Longley P. A. (2018). Geospatial Analysis: A comprehensive guide to principles, techniques and software tools. 6th edition. The Winchelsea Press, UK

Farmer, R., Oakman, P., and Rice, P. (2016). A review of free online survey tools. MSOR Connections. 15. 10.21100/msor.v15i1.311.

Fuady, M., Nurhakim, N., \& Riswan, R. (2018). Permodelan Endapan Laterit Di Desa Kiram, Karang Intan, Kabupaten Banjar, Kalimantan Selatan. Jurnal Geosapta, 4(01).

Haldar, S.K. (2018). Mineral Exploration (Second Edition), Elsevier, Pages 47-68, ISBN 9780128140222, DOI : 10.1016/B978-0-12-814022-2.00003-4.

Nakayama, Y. and Mori, S. (2012). "FOSS4G Based Mobile Web-GIS for Field Survey in Natural Environmental Studies." In 9th International Conference on Ubiquitous Intelligence and Computing and 9th International Conference on Autonomic and Trusted Computing. DOI:10.1109/uic-atc.2012.38.

Nurhakim, 2000, Estimasi Sumber Daya Batubara Berbasis Sistem Informasi Geografis. Thesis tidak diterbitkan. Bandung: Program Pascasarjana Institut Teknologi Bandung (ITB).

Nurhakim. (2002). Peranan Teknologi Sistem Informasi Bagi Industri Pertambangan di Era Otonomi Daerah, Orasi ilmiah pada Yudisium FT Unlam Periode II 2001/2002, 26 September 2002. Banjarbaru: Fakultas Teknik Univrsitas Lambung Mangkurat

Nurhakim. (2006). Mineral Inventories and Map Digitization as Tools to Help Local Government to Optimize Land-Use Planning in Kota Banjarbaru, Seminar on Science \& Technology 2004 Pekanbaru, 7 - 8 Juli 2004. Jakarta: Forum HEDS, ISBN 979-957268-1

Nurhakim, N., Dwiatmoko, U., Romla, N. H., \& Adip, M. (2016). Identifikasi Potensi Endapan Bijih Besi Laterit Di Bagian Tengah Pulau Sebuku, Provinsi Kalimantan Selatan. INFO-TEKNIK, 12(2), 48-53.
Prahasta, E. (2006). Membangun Aplikasi Web-Based GIS dengan Mapserver. Bandung: Informatika

Pusat Sumberdaya Geologi. (2014). Bimbingan Teknis Penyelidikan Dan Eksplorasi Sumber Daya Mineral Dan Energi Fosil. Bandung: Kementerian Energi dan Sumber Daya Mineral.

Saputra, J. E., Nurhakim, N., \& Riswan, R. (2019). Inventarisasi Keterdapatan Batuan Untuk Material Konstruksi Jalan Di Kecamatan Bati-Bati Dan Sekitarnya. Jurnal Himasapta, 4(01).

Speedtest.net. (2019). Speedtest Global Index, https://www.speedtest.net/global-index May 2019.

Standar Nasional Indonesia 4726:2019 Tentang Pedoman Pelaporan Sumber Daya dan Cadangan Mineral. (2019). Jakarta: Badan Standarisasi Nasional

Standar Nasional Indonesia 5015:2019 Tentang Pedoman Penyusunan Sumber Daya dan Cadangan Batubara. (2019). Jakarta: Badan Standarisasi Nasional

Standar Nasional Indonesia 6728:2015 Tentang Penyusunan Neraca Spasial Sumber Daya Alam Bagian 4 : Sumber Daya dan Cadangan Mineral dan Batubara (2015). Jakarta: Badan Standarisasi Nasional Sugarbaker, L.J., and Carswell, W.J., Jr. (2011). The National Map: U.S. Geological Survey Fact Sheet 2011-3042, https://pubs.usgs.gov/fs/2011/3042

Syahid, A., Nurhakim, N., \& Triantoro, A. (2017). Perancangan Sistem Informasi Cadangan Batugamping Berbasis Web Pada Pt Pama Indo Mining. Jurnal Geosapta, 3(2).

Tryono, A., Nurhakim, N., \& Riswan, R. (2017). Studi Rencana Wilayah Pertambangan Rakyat Menggunakan Sistem Informasi Geografis Di Wilayah Kecamatan Kahayan Tengah. Jurnal Geosapta, 3(2).

Yousefi, M., Kreuzer, O. P., Nykänen, V., Hronsky, J.M.A. (2019). Exploration information systems - A proposal for the future use of GIS in mineral exploration targeting, Ore Geology Reviews, Volume 111, 2019, 103005, ISSN 0169-1368, DOI: 10.1016/ j.oregeorev.2019.103005 